\title{
3. CRUISE Ew9209: SITE SURVEY FOR LEG 154
}

\author{
Gregory S. Mountain ${ }^{2}$ and William B. Curry ${ }^{3}$
}

\section{INTRODUCTION}

The Ceara Rise intersects the flow paths of the ocean's principal deep-water masses. Sediments covering this feature, as a result, provide a record of changes in surface productivity, deep-water chemistry, circulation, and carbonate dissolution throughout the entire Cenozoic. Previous work (e.g., ODP Legs 108, 113, 115, and 130) suggests that such paleoceanographic histories can be reconstructed with drill sites arrayed along a bathymetric transect, provided one has previous knowledge of sediment distribution, depositional processes, and the structural history. This baseline information is needed to ensure that specific drill sites are properly located and to enable the rock record to be understood in its regional context. The data available in 1992 did not meet these requirements. Consequently, the Ocean Drilling Program (ODP) of the National Science Foundation (NSF) funded Cruise 9209 of the Maurice Ewing (Ew9209) to augment the available data; in this chapter, we outline the operations and results of this expedition.

Data collected across the Ceara Rise before Ew9209 demonstrated the feasibility of a paleoceanographic drilling leg by showing that the Cenozoic section is approximately $1 \mathrm{~km}$ thick, relatively intact, and devoid of regional tectonic disturbances. These facts had been determined by:

1. Piston cores collected during various cruises of the Vema and Conrad that passed through the region (Damuth, 1977) and by a large number of cores specifically concentrating on the rise itself collected during Knorr Cruise 110 (Curry and Lohmann, 1990);

2. Inferences from echogram character (Damuth, 1975);

3. One rotary-drilled Deep Sea Drilling Project (DSDP) hole on the rise (DSDP Site 354; Supko, Perch-Nielsen, et al., 1977) and another on the nearby Ceara Abyssal Plain (DSDP Site 142; Hayes, Pimm, et al., 1972);

4. Regional geophysical syntheses (Kumar and Embley, 1977); and

5. Seismic surveys that all pre-date 1975.

Despite the information contained in these data, detailed bathymetry, shallow sub-bottom stratigraphy, and regional seismic stratigraphy were poorly defined. The concerns for drilling were based on the possibility that gravity-induced sediment failure or bottom currents had redistributed or completely removed pieces of the paleoceanographic record that was sought. Considering the steepness of the terrain, the suspected flow paths and intensities of past deep-water circulation, plus the quality and distribution of existing data, a detailed and high-quality survey was warranted. Survey and sampling technologies employed on Ew9209, coupled with a modern understanding of Ceara Rise sediments as paleoceanographic monitors, provided a greatly improved framework with which to plan ODP Leg 154 and interpret its results.

\footnotetext{
' Curry, W.B., Shackleton, N.J., Richter, C., et al., 1995. Proc. ODP, Init. Repts., 154: College Station, TX (Ocean Drilling Program).

${ }^{2}$ Lamont-Doherty Earth Observatory, Palisades, NY 10964, U.S.A.

${ }^{3}$ Department of Geology and Geophysics, Woods Hole Oceanographic Institution, Woods Hole, MA 02543, U.S.A.
}

\section{OPERATIONS}

Cruise Ew9209 began in Bridgetown, Barbados, on 23 August 1992 and ended at the same port on 25 September. Both to and from the survey area, ship speed was maintained at roughly $10 \mathrm{kt}$ to permit underway data acquisition consisting of Hydrosweep swath bathymetry, $3.5-\mathrm{kHz}$ echo-sounding, and total field magnetics and gravity measurements. We deviated slightly and slowed to $6.5 \mathrm{kt}$ to conduct a 2-day Hydrosweep, echo-sounding, and seismic survey on the Amazon Fan during the transit from the Ceara Rise back to Bridgetown (Fig. 1). This activity was supported by JOI/USSAC site-survey augmentation funds for potential drilling during ODP Leg 155 and is not discussed further in this report.

During the primary survey of the Ceara Rise, we spent 22 days collecting Hydrosweep swath bathymetry and $3.5-\mathrm{kHz}$ echo-sounding profiles. For 18 of these days, we also collected high-resolution, digitally processed single-channel seismic (SCS) data, plus total field magnetics and gravity measurements along the cruise track shown in Figure 2. Eleven sonobuoy seismic wide-angle reflection and refraction experiments were performed (Fig. 3) during the SCS operations. In addition, we recovered 15 wide-barrel piston cores (Fig. 3 ).

\section{Navigation}

Survey speed was reduced from 10 to $6.5 \mathrm{kt}$ during SCS acquisition. Navigation for most of the survey was based on ordinarily excellent 24-hr Global Positioning Satellite (GPS) coverage that was made even more outstanding for the following reason. The GPS data are typically degraded to allow access by civilian users, providing accuracy to roughly $\pm 50 \mathrm{~m}$. During U.S. military operations in the Mideast between 1 and 21 September, however, public data quality was maintained at much higher levels, probably approaching $\pm 10 \mathrm{~m}$. This interval spanned all but the first 4 days of surveying on the Ceara Rise.

\section{Swath Bathymetry}

Hydrosweep bathymetric data are collected by a hull-mounted transducer array that operates at $15.5 \mathrm{kHz}$. Pings are transmitted at intervals that vary by water depth; over the Ceara Rise these ranged from 4 to $8 \mathrm{~s}$ (roughly 13 to $26 \mathrm{~m}$ of distance along track). As many as 59 beams can be detected athwartships, providing a cross-track swath of water-depth calculations that is as wide as $190 \%$ of the water depth. The quality of bathymetric data depends on various factors, including sea state and accurate measurement of sound velocity. Seas were exceptionally calm for the entire survey. Expendable bathythermograph (XBT) data were collected each day to supplement along-track velocity-profiling calculations that are part of the Hydrosweep acquisition system. Nonetheless, moderate beam editing was performed with software developed at Lamont-Doherty Earth Observatory. This was accomplished by displaying cross-track topography on a computer screen and removing individual beams that appeared visually suspect. Editing typically eliminated three to six of the outermost beams. We also applied a static correction to account for a modest ship's list, as well as a smoothing routine that performed a running average across the 59 beams received with each ping. Though a rigorous study has not 
Figure 1. Generalized location map of the Leg 154 study area and the Maurice Ewing Cruise 9209 (Ew9209) site survey. The locations of DSDP Sites 354 and 142 are shown. Inset shows ship track between Barbados and the study area. Bathymetric contours are in meters.
Figure 2. Cruise track for the Ew9209 site survey plotted on the updated bathymetry of the Ceara Rise. The bathymetric contours were produced using the Ew9209 Hydrosweep center beam data gridded at $0.05^{\circ}$ increments.
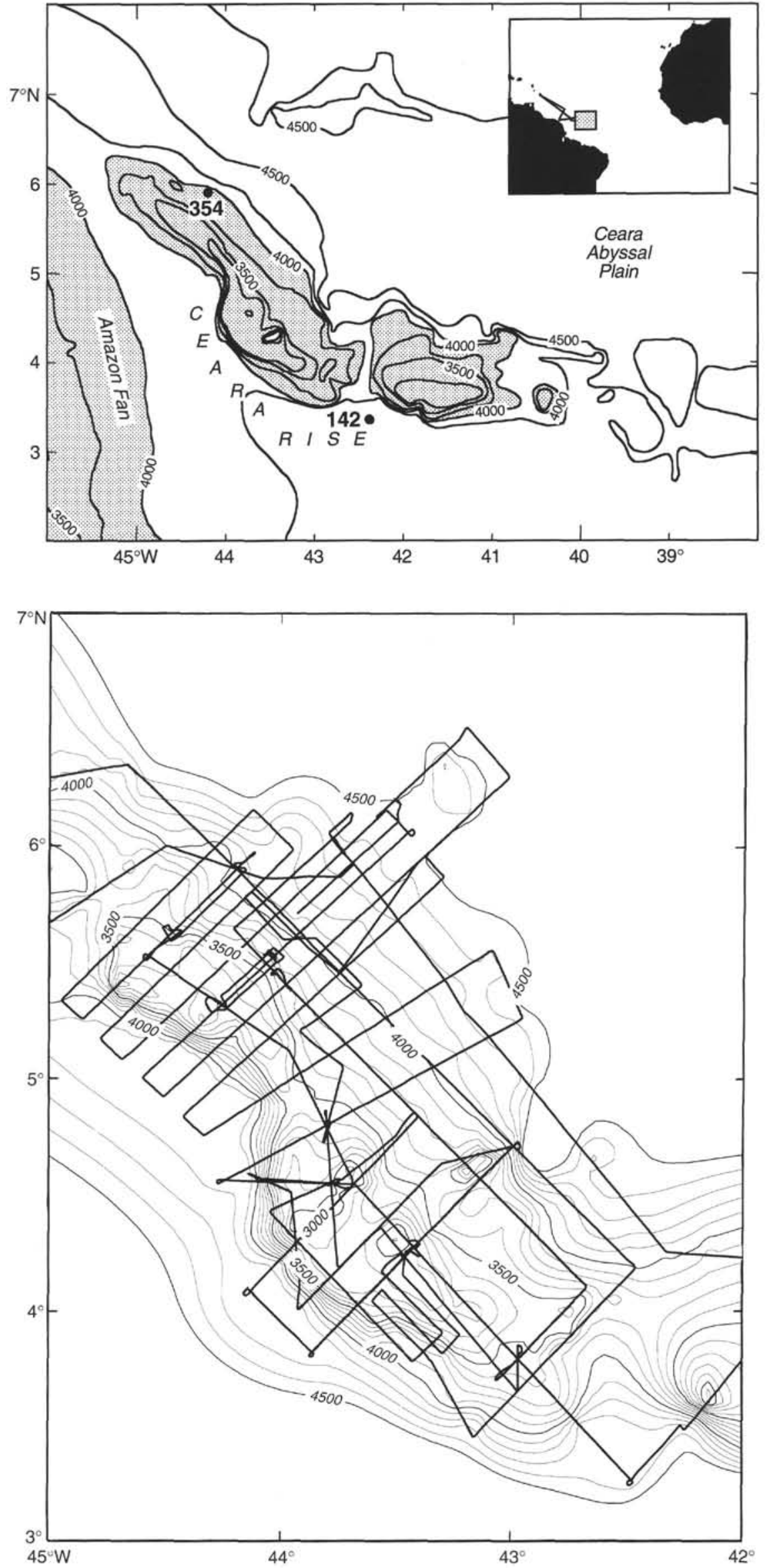


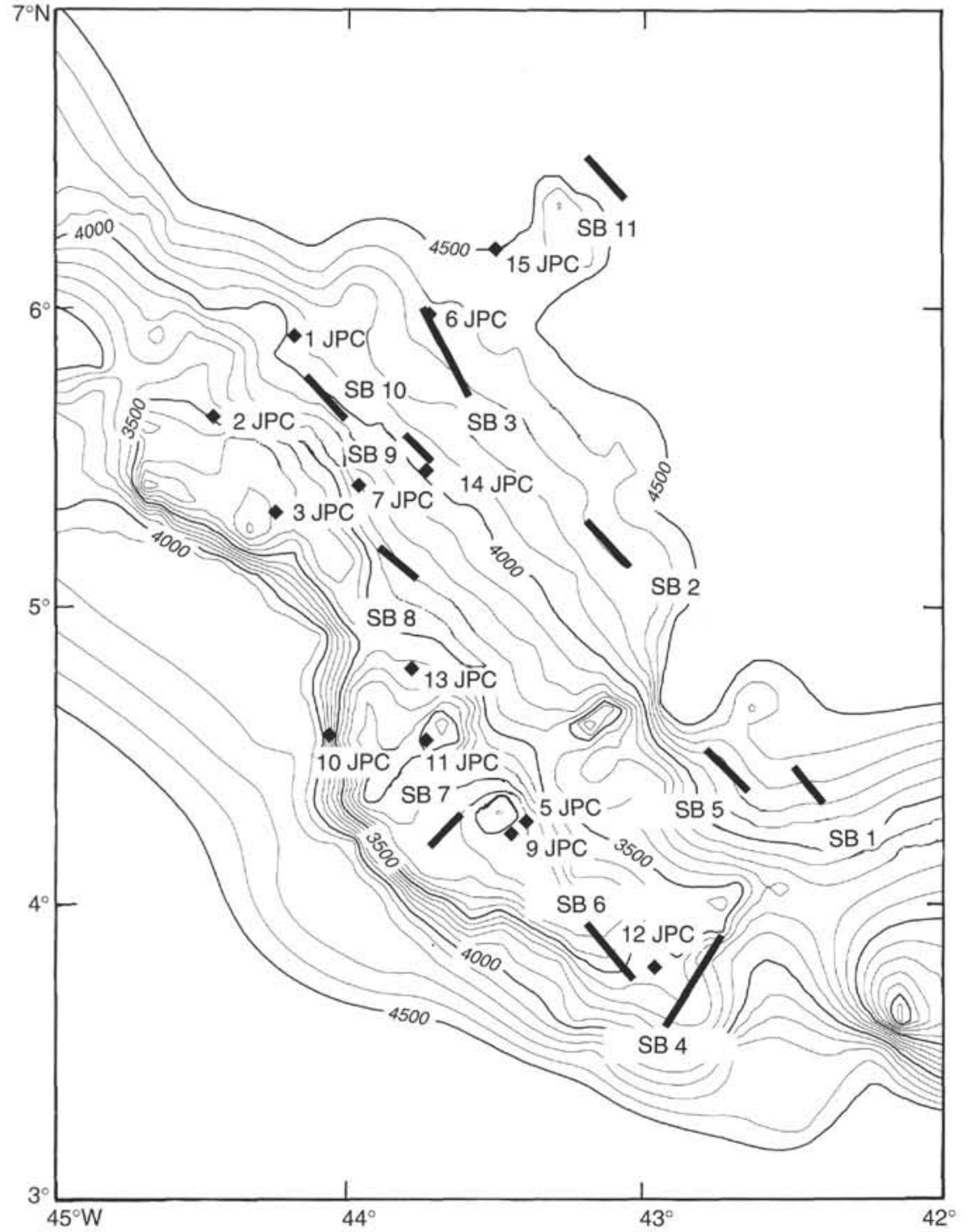

Figure 3. Location of 11 sonobuoy experiments and 15 piston cores (labeled "JPC" for "jumbo piston core"), plotted on the bathymetry of Ceara Rise. Bathymetry is the same as in Figure 2. been done, errors among the many crossings throughout our survey suggest that relative accuracy approached $\pm 20 \mathrm{~m}$, though this is also a function of navigational precision. For the data presented in Figures 2 and 3, only the center beam data were used to produce the bathymetric contours. For each site report, a high-resolution map of the area immediately surrounding each drilling site was produced, using edited and smoothed swaths of Hydrosweep data (see the "Background and Objectives" sections of each site chapter).

\section{Seismics}

We towed an array of six air guns at $6.5 \mathrm{kt}$ for the majority of our SCS survey. Total air volume was $1350 \mathrm{in}^{3}$, distributed among chambers that varied in size from 80 to $500 \mathrm{in}^{3}$ and which provided a $50-\mathrm{ms}$ pulse centered at roughly $30 \mathrm{~Hz}$. The guns were pressurized to 2000 psi, towed at roughly $20 \mathrm{ft}$, and fired every $10 \mathrm{~s}$ when profiling, and every $15 \mathrm{~s}$ when also collecting sonobuoy data. A 4-channel streamer was towed with an offset of $268 \mathrm{~m}$ from the center of the gun array to the center of the nearest active section. Data from each section (12.5, 25,50 , and $50 \mathrm{~m}$ in length) were recorded separately to provide processing flexibility. We lacked depth transducers on the streamer, and though we attempted to ballast it to tow at 20 to $30 \mathrm{ft}$ below sea level, the character of the seafloor echo indicates that it was closer to 50 , and sometimes $60 \mathrm{ft}$.
The SCS data were sampled at $2 \mathrm{~ms}$; a total of $7 \mathrm{~s}$ were recorded at each shotpoint using four channels of the Ewing's DSS-240 system. During simultaneous sonobuoy recordings, the sample interval was $4 \mathrm{~ms}$, dropping the anti-alias bandpass from $0-320 \mathrm{~Hz}$ to $0-160 \mathrm{~Hz}$; furthermore, the recording window at these times was increased from 10 to $15 \mathrm{~s}$. All seismic data were recorded on Fujitsu 3480 tape cartridges and processed during the cruise using JDseis software. This processing comprised the following procedures: (1) amplitude normalization among the four traces based on the first 100 shots of each SCS line; (2) normal-moveout correction and four-trace stacking based on an assumed velocity of $1500 \mathrm{~m} / \mathrm{s}$; (3) spherical divergence correction of trace amplitudes; (4) bandpass filtering of $20-70 \mathrm{~Hz}$ with roll-off widths of $10 \mathrm{~Hz}$ on the low end and $40 \mathrm{~Hz}$ on the high end; and (5) time-varying gain adjustment. Reflection profiles were displayed on a 300 -dpi laser printer and interpreted on board the Maurice Ewing.

All 11 wide-angle reflection and refraction experiments used SSQ41A expendable sonobuoys launched during SCS operations (Fig. 3). The gun array was as described above; data were recorded on tape cartridges for $12 \mathrm{~s}$ out of each 15 -s shot interval, and sampled at $4 \mathrm{~ms}$. Anti-aliasing bandpass filtering of $0-160 \mathrm{~Hz}$ was the only processing applied before display as traveltime-offset data using JDseis software. Refracted arrivals were interpreted and their velocities calculated graphically after display on a 300-dpi laser printer. 
Table 1. Results of sonobuoy experiments.

\begin{tabular}{ccccccccccccc}
\hline & \multicolumn{9}{c}{ Wide-angle reflections } & \multicolumn{4}{c}{ Refractions } \\
Buoy & T, sf & V & T, rfl & V & T, rfl 2 & V & T, rf 3 & V & T, rfr 1 & V & T, rfr 2 & V \\
\hline 1 & 5.58 & 1.48 & 6.16 & 1.86 & 6.47 & 2.38 & & & 6.45 & 3.11 & 7.20 & 5.62 \\
2 & 5.65 & 1.46 & 6.53 & 1.55 & & & & & 6.75 & 4.91 & & \\
3 & 5.74 & 1.49 & 6.24 & 1.77 & 6.64 & 2.36 & & & 7.35 & 5.91 & & \\
4 & 4.78 & 1.50 & 5.02 & 1.59 & 5.66 & 2.18 & 5.88 & 2.54 & 6.20 & 4.54 & 7.45 & 7.95 \\
5 & 5.57 & 1.47 & 5.96 & 1.71 & 6.37 & 2.21 & 6.85 & 2.64 & 7.20 & 5.22 & 7.72 & 8.27 \\
6 & 4.78 & 1.50 & 4.95 & 1.82 & 5.71 & 2.21 & & & 7.15 & 4.14 & 7.85 & 5.16 \\
7 & 4.14 & 1.46 & 4.63 & 1.78 & 4.85 & 2.32 & 5.05 & 2.60 & 5.55 & 4.09 & 6.40 & 5.69 \\
8 & 4.89 & 1.46 & 5.12 & 1.60 & 5.57 & 1.84 & 5.85 & 2.60 & 6.60 & 5.34 & 7.00 & 6.08 \\
9 & 5.22 & 1.46 & 5.78 & 1.71 & 6.18 & 2.35 & & & 6.90 & 3.80 & & \\
10 & 6.11 & 1.51 & & & & & & & & & &
\end{tabular}

Notes: Wide-angle reflections measure the sound velocity above the reflecting surface, whereas refractions measure the sound velocity below the refracting surface. $T=$ two-way traveltime $(\mathrm{s}) ; \mathrm{sf}=$ seafloor; $\mathrm{V}=$ sound velocity $(\mathrm{km} / \mathrm{s}) ; \mathrm{rfl} 1, \mathrm{rfl} 2$, and $\mathrm{rfl} 3=\mathrm{reflecting}$ surfaces 1,2, and 3; and $\mathrm{rfr} 1$ and $\mathrm{rfr} 2$ = refracting surfaces 1 and 2 .

Wide-angle reflections, by contrast, were traced on a computer screen and modeled using JDseis (Table 1). We typically obtained two or three velocities from oblique reflections in the sediment column and one or two refractions from within basement. The reflection velocities were reduced to velocities posted at layer midpoints in one-way traveltime. A linear regression was applied after one value from Sonobuoy 6 was eliminated. The result provided the curve of two-way traveltime vs. depth (both measured below seafloor) shown in Figure 4. All sub-bottom depths and thicknesses described in this paper were derived from this measure of the traveltime-to-depth conversion.

\section{Piston Coring}

We deployed 15 large-diameter (4 in.), lined piston cores (Table 2), but only 13 of these were successful. Two coring attempts failed to trip on contact with the seafloor; the sediments recovered in these cores were significantly disturbed. We used a launch/recovery system designed and built by J. Broda of Woods Hole Oceanographic Institution, and this was the first coring attempted from the Ewing. Though most cores were $60 \mathrm{ft}$ in length, 80 -ft core lengths could have been handled. We consistently had difficulties extracting cores from the stainless steel pipes because of imploded liners. The crushed sections often occurred in the middle of a core (not at the top), and we concluded that wire rebound during trip (not incomplete penetration) was a likely cause. The lack of torque-balanced core wire very likely contributed to this problem. These difficulties, along with breakdown of the hydraulic pump that powers the core winch, limited the number of deployments to fewer than planned. Nonetheless, we were very satisfied with the quality (excellent), length ( 10.41 to $14.47 \mathrm{~m}$ ), and distribution (from 2900 to $4500 \mathrm{~m}$ water depth) of the recovered sediments.

\section{RESULTS}

\section{Marine Geologic Setting}

The Ceara and Sierra Leone rises formed as one feature during excess volcanism on the Mid-Atlantic Ridge at about $80 \mathrm{Ma}$ (Campanian; Kumar and Embley, 1977). They are now widely separated as conjugate aseismic ridges (Fig. 5). The Ceara Rise is surrounded by seafloor with an average depth of about $4500 \mathrm{~m}$ and is draped with approximately $1 \mathrm{~km}$ of undisturbed lithogenic and biogenic sediments (Supko, Perch-Nielsen, et al., 1977). DSDP Site 354 was located on the northern flank of the Ceara Rise at a depth of about $4000 \mathrm{~m}$ (Fig. 1). Although these sediments were only spot cored, a generalized history of the area was reconstructed from this investigation.

Ceara Rise is asymmetric in cross section (Fig. 6). Slopes along the southwest side commonly exceed $5.7^{\circ}$, whereas those on the northeast side are $\sim 1.4^{\circ}$ or less. The rise is bounded on the northeast by the Ceara Abyssal Plain and on the southwest by the Amazon Fan, whose deposits lap onto the downfaulted base of the Ceara Rise at

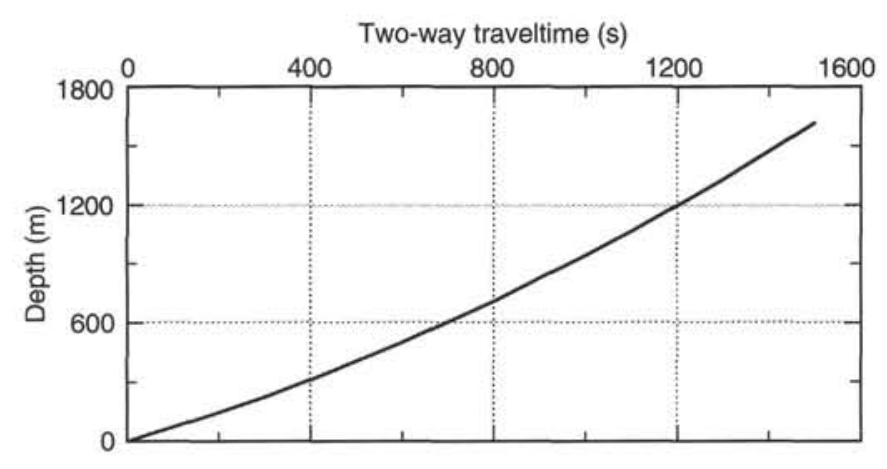

Figure 4. Two-way traveltime (TWT) vs. depth in sediment; results from the sonobuoy experiments.

about $4100 \mathrm{~m}$ below sea level (mbsl) water depth. The abyssal plain to the northeast is deeper $(4500-4700 \mathrm{mbsl})$ and exhibits topographic features and surface roughness that suggest that strong bottom currents are actively modifying the sediments.

The swath bathymetric survey of the Ceara Rise covered between $40 \%$ and $70 \%$ of the northern rise. On the basis of this survey, we have produced the bathymetric contours shown in Figure 2. The rise consists of a series of platform-shaped shoals oriented in a northwestsoutheast direction. The platform tops of the rise reach about 3200 mbsl, but they are punctuated with small, sedimented features that reach minimum depths of about $2800 \mathrm{mbsl}$. The shallowest portions of the Ceara Rise were located in the southern half of our survey area. In two areas $\left(4^{\circ} 30^{\prime} \mathrm{N}, 43^{\circ} 40^{\prime} \mathrm{W}\right.$, and $\left.4^{\circ} 20^{\prime} \mathrm{N}, 43^{\circ} 30^{\prime} \mathrm{W}\right)$, the shallowest depths are less than $3000 \mathrm{mbsl}$. One shallow pinnacle, uncharted before this cruise, reached a depth of $<2600 \mathrm{~m}$, but little evidence for sediment accumulation was present on its peak or steep slopes.

\section{Piston Coring}

The piston cores contained hemipelagic sediments that vary in carbonate concentration from $0 \%$ to $70 \%$. Shipboard stratigraphic investigations were able to locate two coccolith datums (Fig. 7): the acme of Emiliania huxleyi, which occurs in oxygen isotope stage $5 \mathrm{~A}$, and the extinction of Pseudoemiliania lacunosa, which occurs in oxygen isotope stage 12 (Thierstein et al., 1977). On the basis of these identifications, we determined that several cores had penetrated to nearly 0.5 $\mathrm{Ma}$. Sedimentation rates vary from an average of 2.5 to $3 \mathrm{~cm} / \mathrm{k}$.y., as determined from the southern cores, to 4 to $5 \mathrm{~cm} / \mathrm{k}$.y. from the northern cores. The regional differences in sedimentation rate reflect the proximity to the Amazon Fan and its great influence on the noncarbonate input into the sediments of the Ceara Rise. Shore-based stratigraphic analysis has confirmed these initial sedimentation-rate estimates. 


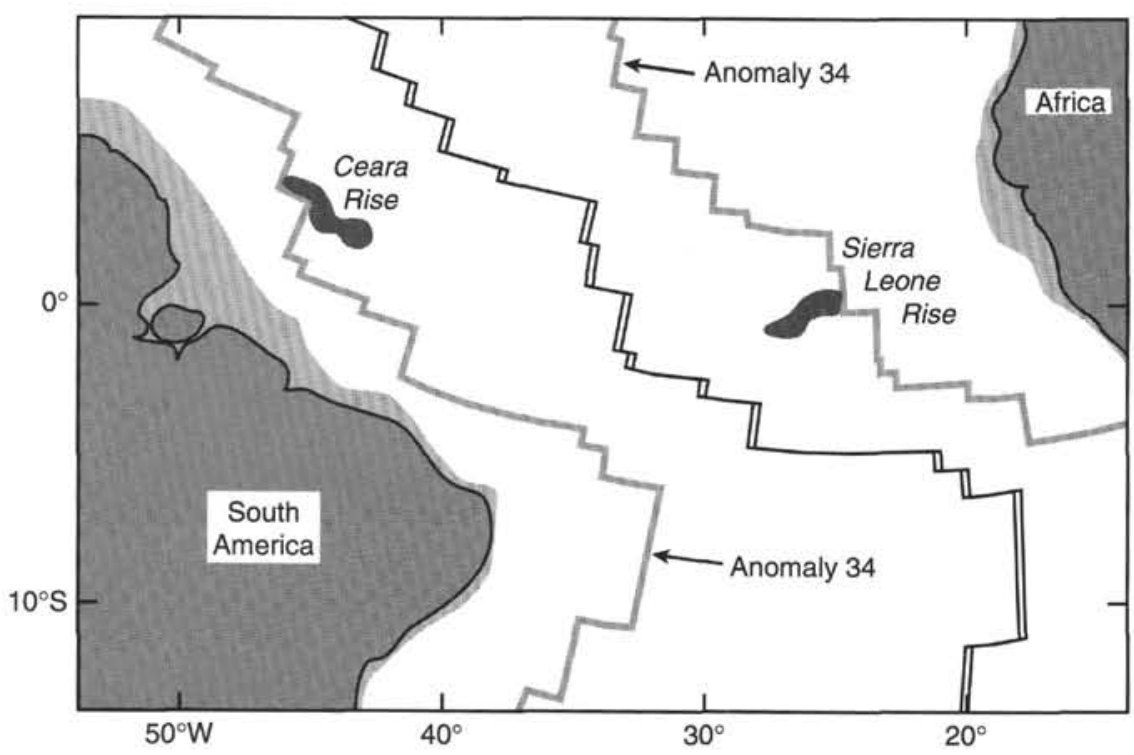

SW
Figure 5. Regional locations of the Ceara and Sierra Leone rises, which are conjugate features and are located symmetrically about the Mid-Atlantic Ridge at about $5^{\circ} \mathrm{N}$ latitude today.

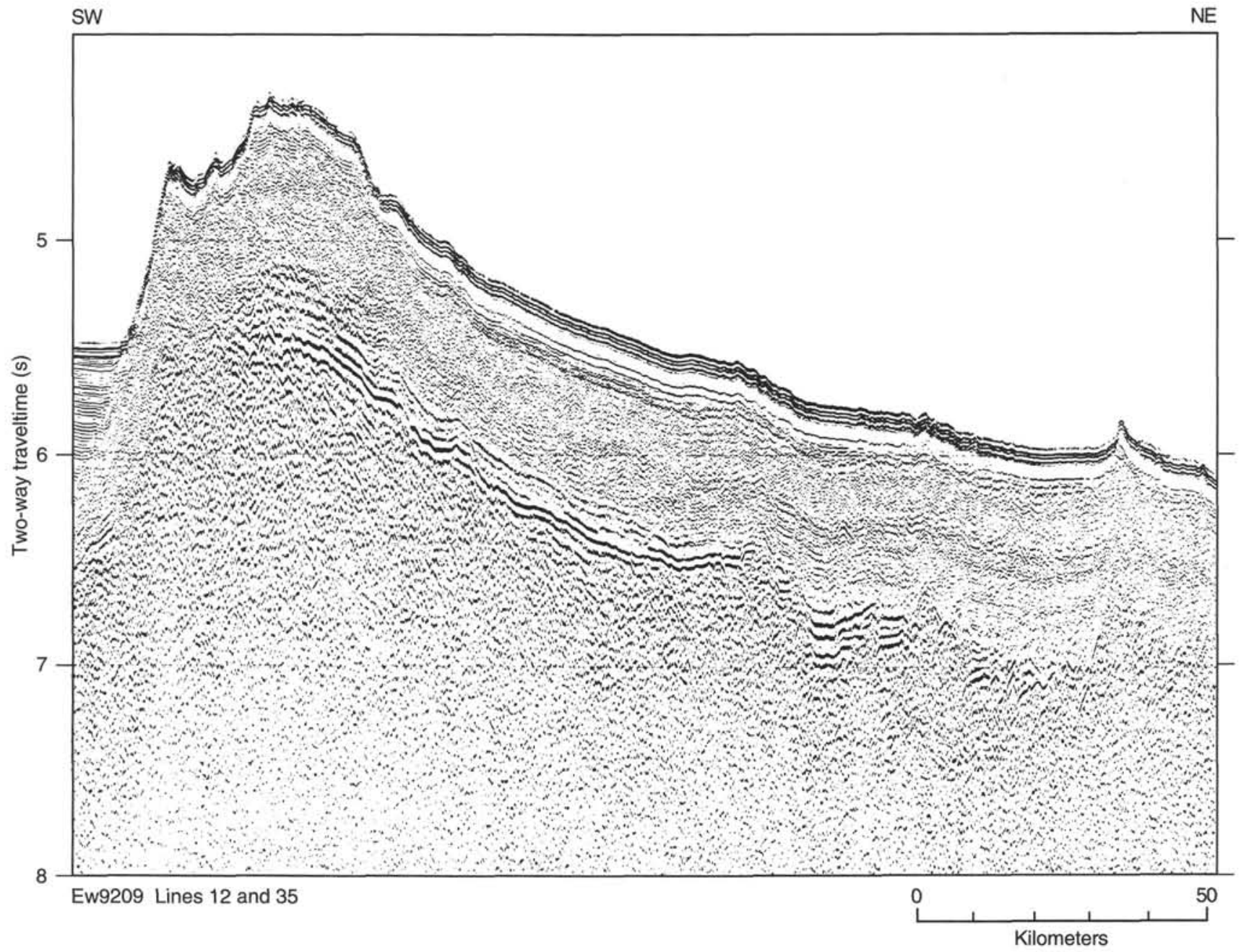

Figure 6. Cruise Ew9209 SCS Lines 12 and 35 (composite profile) illustrating the asymmetry of the Ceara Rise. Slopes on the western side exceed $5^{\circ}$, whereas slopes on the eastern side are closer to $1.4^{\circ}$. 
Table 2. Location and water depth of piston cores collected on Cruise Ew9209.

\begin{tabular}{cccc}
\hline Core & $\begin{array}{c}\text { Latitude } \\
(\mathrm{N})\end{array}$ & $\begin{array}{c}\text { Longitude } \\
(\mathrm{W})\end{array}$ & $\begin{array}{c}\text { Depth } \\
(\mathrm{m})\end{array}$ \\
\hline 1 & $5^{\circ} 54.4^{\circ}$ & $44^{\circ} 11.7^{\circ}$ & 4056 \\
2 & $5^{\circ} 38.1^{\circ}$ & $44^{\circ} 28.2^{\circ}$ & 3528 \\
3 & $5^{\circ} 18.8^{\circ}$ & $44^{\circ} 156^{\circ}$ & 3228 \\
4 & $5^{\circ} 32.0^{\circ}$ & $44^{\circ} 02.3^{\circ}$ & 3786 \\
5 & $4^{\circ} 16.3^{\circ}$ & $43^{\circ} 24.9^{\circ}$ & 3030 \\
6 & $5^{\circ} 58.6^{\circ}$ & $43^{\circ} 44.5^{\circ}$ & 4340 \\
7 & $5^{\circ} 24.2^{\circ}$ & $43^{\circ} 58.9^{\circ}$ & 3714 \\
8 & $4^{\circ} 32.7^{\circ}$ & $43^{\circ} 47.5^{\circ}$ & 3033 \\
9 & $4^{\circ} 13.8^{\circ}$ & $43^{\circ} 27.9^{\circ}$ & 3044 \\
10 & $4^{\circ} 33.8^{\circ}$ & $44^{\circ} 4.8^{\circ}$ & 3770 \\
11 & $4^{\circ} 32.8^{\circ}$ & $43^{\circ} 45.2^{\circ}$ & 2902 \\
12 & $3^{\circ} 46.8^{\circ}$ & $42^{\circ} 58.8^{\circ}$ & 3573 \\
13 & $4^{\circ} 47.3^{\circ}$ & $43^{\circ} 48.1^{\circ}$ & 3376 \\
14 & $5^{\circ} 27.2^{\prime}$ & $43^{\circ} 45.1^{\prime}$ & 4013 \\
15 & $6^{\circ} 12.0^{\circ}$ & $43^{\circ} 30.9^{\circ}$ & 4492 \\
\hline
\end{tabular}

\section{Echo-sounding}

Hull-mounted $3.5-\mathrm{kHz}$ profiles were collected throughout the cruise to characterize the uppermost few tens of meters of sediment, assess the recent history of sedimentation, and locate optimum piston core targets. Based on a small number of cruise tracks, Damuth (1975) mapped much of the Ceara Rise with a mantle of hyperbolic echoes that suggested ubiquitous basement outcrops, structural control of bedform morphology, and/or seabed scoured by currents. Kumar and Embley (1977) reported regions of migrating sediment waves on the northeast flank at $\sim 4200 \mathrm{~m}$ water depth.

Most of the survey area from the crest of the Ceara Rise down to $4000 \mathrm{~m}$ on the northeast flank shows undulating seafloor with continuous echoes down to $20 \mathrm{~m}$ below seafloor (mbsf) (Fig. 8). Not surprisingly, hyperbolic echoes are observed in the few regions of basementcontrolled morphology and along the steep southwest flank of the rise. These examples show apexes at various heights, caused by highly irregular seafloor and side echoes.

A different type of hyperbolic echo was detected at several locations throughout the survey. This type shows crisp, closely spaced hyperbolae whose peaks align with a nearly level surface (Fig. 9). We suggest this is evidence of erosional furrows cut into the seafloor by strong bottom currents (Flood and Hollister, 1974). Most examples were found along the base of the northeast flank of the Ceara Rise in water depths ranging from 4480 to $4590 \mathrm{~m}$. However, one especially clear example was crossed several times at much shallower water depths (3250-3500 m) in the vicinity of fairly steep topography near $3^{\circ} 48^{\prime} \mathrm{N}, 42^{\circ} 58^{\prime} \mathrm{W}$. We had no bottom camera for confirmation, but we determined a nearly north-south orientation to this set of hyperbolic echoes by profiling in a tight circle. As described by Embley et al. (1980), the curvature of hyperbolic echoes depends on the angle between the ship's heading and the bedforms themselves: the hyperbolae are steepest when profiling perpendicular to the orientation of the furrows. With decreasing angle of intersection, the observed hyperbolae broaden until, at a limit, their sides are falsely imaged as sub-bottom reflections parallel to the seafloor. The ship's heading at this orientation is then the same as that of the furrows. Furthermore, based on the fact that the echo-sounding beam is roughly $3^{\circ}$ wide, we estimate that at $3500 \mathrm{~m}$ water depth this "footprint" is roughly $180 \mathrm{~m}$ in diameter. For hyperbolic echoes to have been detected, therefore, these north-south oriented furrows must be spaced far closer than this, probably $100 \mathrm{~m}$ or less.

\section{Seismic Stratigraphy}

Prior surveys of the Ceara Rise were conducted with smallvolume air gun, analog seismic recording systems typically towed at

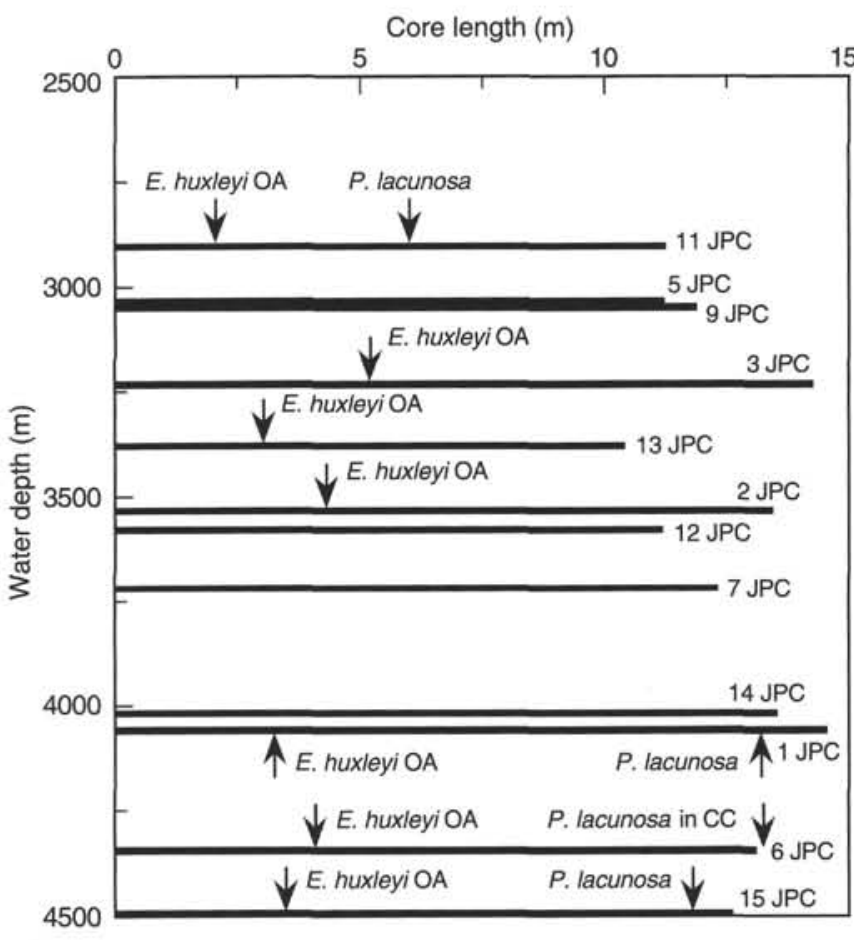

Figure 7. Shipboard biostratigraphic age datums for Cruise Ew9209 piston cores. $\mathrm{JPC}=$ jumbo piston core, $\mathrm{CC}=$ core catcher, and $\mathrm{OA}=$ onset of acme.

$10 \mathrm{kt}$ or more. Slower tow speeds, a tuned air-gun array, digital recording, stacking, and processing combined to achieve greatly improved seismic data quality during Cruise Ew9209. We successfully imaged the entire sediment column down to the top of oceanic crust (perhaps deeper) across the survey area, from the crest of the Ceara Rise out onto the Amazon Fan to the southwest and to the edge of the Ceara and Demarrera abyssal plains to the northeast. Nonetheless, it is apparent that on the whole, Ceara Rise sediments are not acoustically well layered. Laterally continuous reflectors are found in the uppermost 100 to $250 \mathrm{~ms}$, and in the basal $100 \mathrm{~ms}$, but reflections within the intervening section are distinctively discontinuous and irregularly shaped. Earlier profiles revealed the uppermost layering but detected only a "fuzzy" character for the major middle section; they rarely detected anything deeper.

We divided the Ceara Rise sediments into these three acoustic units (Fig. 10). Reflectors Blue and Purple form the boundaries between Units 1 and 2 and Units 2 and 3 , respectively. Unit 3 rests on a basement reflector, though as described below we are not completely certain that this is the top of the volcanic layer. From top down the general features are as follows: (1) Unit 1 is acoustically stratified, predominantly internally conformable; (2) Unit 2 is pervasively hummocky with very little lateral continuity of reflectors; and (3) Unit 3 is acoustically stratified with numerous onlapping geometries against the underlying basement reflection. Reflectors Red, Yellow, and Orange occur within the seismic units and provide a basis for subdividing them.

\section{Unit 1 (Seafloor to Reflector Blue)}

The shallowest acoustic unit on the Ceara Rise is an interval of acoustically stratified sediment that is generally 100 to $250 \mathrm{~ms}$ thick. The scarcity of reflector terminations within this interval suggests that deposition was predominantly pelagic or hemipelagic. Exceptions to this uniformity are found where gravity processes would be expected, such as along the steep slopes of the southwest flank, in limited areas along the more gently dipping northeast flank, and in regions surrounding basement pinnacles. The air-gun-array signature is roughly 


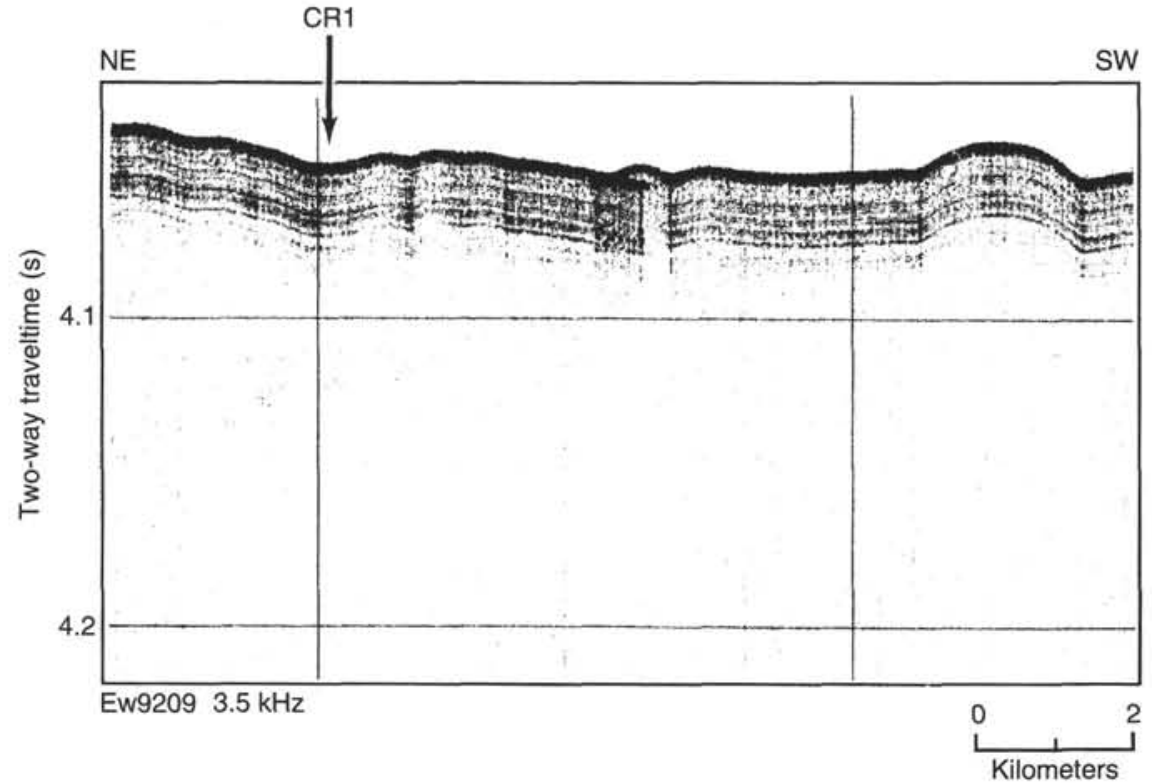

Figure 8 . A representative $3.5-\mathrm{kHz}$ profile across $\mathrm{CR} 1$, proposed location for Site 925 . This sharp seafloor with continuous, sharp, parallel sub-bottom reflectors is typical of the echo character found on the northeast slope of the Ceara Rise down to about $4300 \mathrm{mbsl}$.

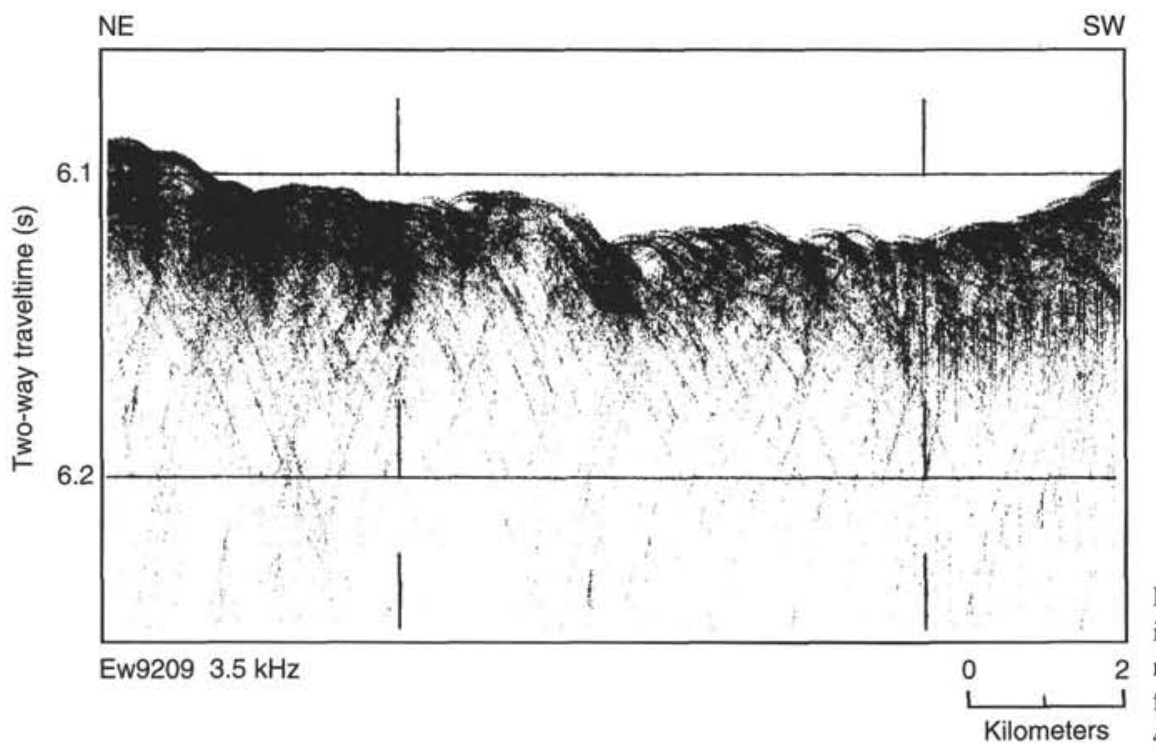

Figure 9. A $3.5-\mathrm{kHz}$ profile showing hyperbolic echoes interpreted as furrows. These features are probably the result of erosion caused by Antarctic Bottom Water. The furrows are most common in water depths near $4480-4590 \mathrm{~m}$ along the northeast foot of the Ceara Rise.
$50 \mathrm{~ms}$ long, and consequently little detail can be resolved at shorter traveltimes below the seafloor.

Reflector Red divides this acoustic unit into two unequal halves: the subunit above Reflector Red is an especially uniform, acoustically stratified sediment blanket generally 100 to $120 \mathrm{~ms}$ thick $(70-85 \mathrm{~m})$ that can be traced continuously along most seismic lines of the survey; the subunit below Reflector Red varies in thickness from 0 to $150 \mathrm{~ms}$ ( 0 to roughly $130 \mathrm{mbsf}$ ) and contains regular to scattered irregular reflectors that commonly onlap the top of the underlying acoustic Unit 2 (Reflector Blue) or are truncated from above by Reflector Red. Examples of truncation are typically observed in areas of regionally steep topography or unusually marked relief on the underlying Reflector Blue.

Correlations to the record from DSDP Site 354 (Fig. 11) places Reflector Red (110 ms; $77 \mathrm{mbsf}$ ) within the Pleistocene calcareous ooze recovered in Cores 1 and 2 . The interval immediately beneath Reflector Red at this location shows several reflectors from 110 to $260 \mathrm{~ms}$ (77-194 mbsf) that lap onto Reflector Blue. This subunit corresponds to Pliocene to upper Miocene calcareous ooze in Cores 3 through 5 of Site 354.

\section{Unit 2 (Reflectors Blue to Purple)}

Seismic Unit 2 shows a discontinuously hummocky character throughout. There are no distinct, mappable surfaces within it, though local-amplitude anomalies draw the eye to specific levels that may appear to be discrete surfaces. Close inspection, however, reveals that these levels are "shingled" or "imbricated" reflecting features, and probably are not single stratal boundaries. This is most apparent in profiles oriented southwest-northeast (i.e., perpendicular to the axis of the rise; Fig. 12). Profiles aligned with the axis of the rise, by contrast, show the discontinuous reflections within Unit 2 to be more symmetrically arranged (Fig. 13). These reflections may originate from true bedding planes, or they may be diffractions from irregular reflecting surfaces that are narrower than the acoustic "footprint" of the seismic source pulse (a few hundred meters in diameter). Whatever the cause, this hummocky character is very similar to the internal acoustic character of major sediment drifts (e.g., the Blake-Bahama Outer Ridge; Fig. 14) and strongly suggests that these sediments on the Ceara Rise have experienced some degree of depositional control by bottom currents. The contrast in acoustic character with the regular 


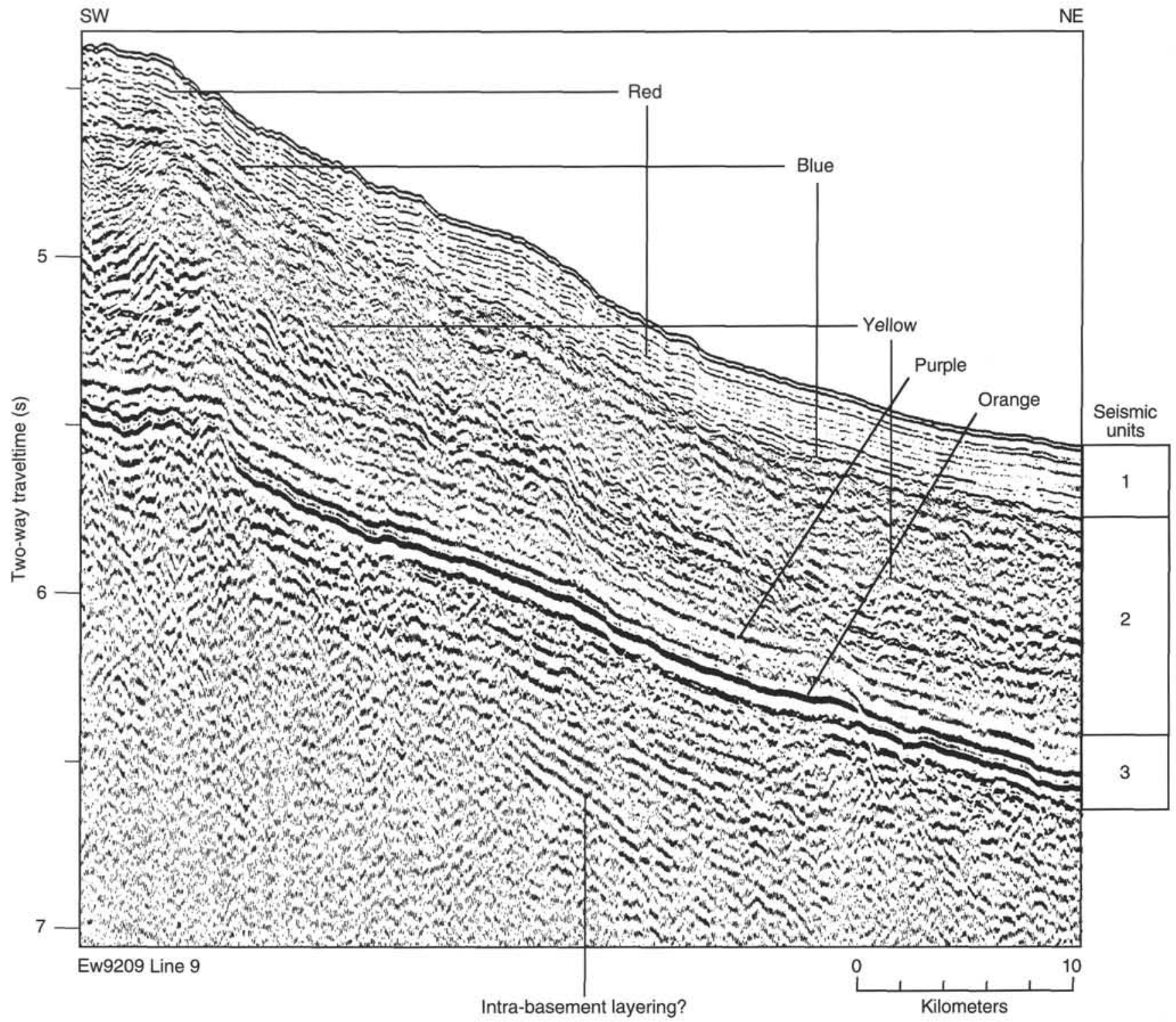

Figure 10. Cruise Ew9209 SCS Line 9, which illustrates the three seismic units and distinctive seismic reflectors found throughout the entire Leg 154 study area.

stratification of the overlying unit is most apparent on the northeast flank of the Ceara Rise in water depths near $3700 \mathrm{~m}$; toward the crest of the rise, acoustic layering near the top of Unit 2 becomes slightly organized, though no reflectors are as smooth and laterally continuous as those of Unit 1. With increasing water depths down the northeast flank of the rise, cryptic stratification and sporadic onlapping geometry are observed at the base of Unit 2.

The DSDP Leg 39 shipboard party noted a "transparent layer" devoid of reflectors between 260 and $600 \mathrm{~ms}$ at DSDP Site 354 (Supko, Perch-Nielsen, et al., 1977). This interval corresponds to the poorly stratified, hummocky unit defined here between Reflectors Blue and Yellow.

Reflector Yellow is a loosely defined feature within Unit 2. Though it cannot be traced as a continuous surface, Reflector Yellow marks a change in the acoustic "hummocks" that characterize Unit 2. Below Reflector Yellow, the lateral dimensions and the vertical scale of these irregularities take on a more "mound-like" aspect than those at shallower burial depths. Hummocks above Reflector Yellow are typically a few hundred meters in both their lateral and vertical dimensions; those beneath it are an order of magnitude larger in both dimensions. Although this can be attributed to the lower acoustic frequencies returned from greater sub-bottom depths, the change is so abrupt that some kind of geologic character must change abruptly as well. Reflector Yellow is probably not a chronostratigraphic surface, and like Reflector Blue, it has analogs in known sediment drifts (e.g., Reflector "X" in the Blake-Bahama Outer Ridge; Markl et al., 1970; Mountain and Tucholke, 1985).

Reflector Blue marks the top of Unit 2 and occurs at $260 \mathrm{~ms}$ (194 mbsf) at DSDP Site 354 (Fig. 11). This places Reflector Blue immediately beneath Core 5, where a 3- to 10-Ma hiatus separates upper Miocene calcareous ooze in Core 5 from middle to upper Miocene chalk in Core 6. Reflectors at the base of Unit 1 lap onto Reflector Blue and suggest that a shorter hiatus could be found a few kilometers from Site 354. Although it is tempting to attribute the contrast in acoustic character between Units 1 and 2 to the ooze/chalk transition, similar contrasts are observed in the Blake-Bahama Outer Ridge, where no corresponding transition is found (Mountain and Tucholke, 1985).

Reflector Yellow occurs at approximately $540 \mathrm{~ms}$ ( $440 \mathrm{mbsf})$ at Site 354 (Fig. 11). The uncertainty in specifying the exact traveltime has two causes. First, instead of a discrete surface, Reflector Yellow is defined as a downward change in acoustic character from small- to large-scale hummocky reflectors; consequently, the exact placement 


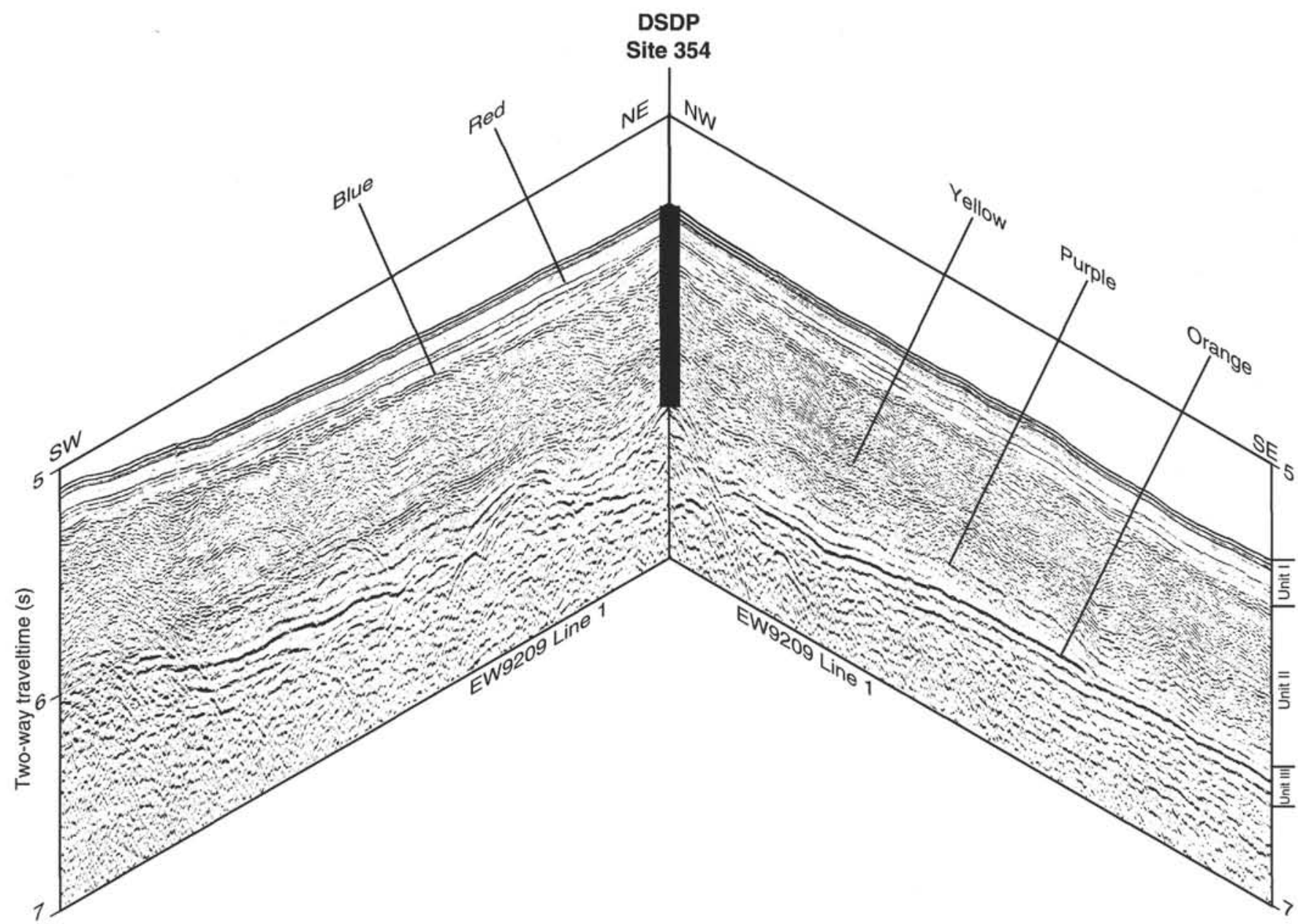

Figure 11. Isometric view of SCS lines through DSDP Site 354, the only previous drill site on the Ceara Rise, showing that Site 354 was drilled on a regional high. The recovered section is thinner and perhaps less continuous than other sedimentary sections in this region. Regional reflectors are shown.

of this change can be debated. Second, uncertainty is compounded by potential errors in the location of Site 354 relative to our seismic data; more than any of the overlying reflectors, Reflector Yellow conforms to basement topography, and consequently its traveltime below seafloor varies by as much as $25 \%$ in just $2 \mathrm{~km}$ along track. The Leg 39 shipboard party noted a reflector at $600 \mathrm{~ms}$ (Supko, Perch-Nielsen, et al., 1977) that is probably our Reflector Yellow. Whichever traveltime to Reflector Yellow is adopted ( 540 vs. $600 \mathrm{~ms}$ ), its tie to Site 354 places it in upper Oligocene chalk. Although the hole was only spot cored, sedimentation rates appear to be uniformly 18 to $21 \mathrm{~m} /$ m.y. from Oligocene through early Miocene time (Fig. 15). The origin of Reflector Yellow has yet to be determined.

\section{Unit 3 (Reflectors Purple to Basement)}

Unit 3 begins with Reflector Purple and is the deepest seismic unit that we identify. It is distinguished from the overlying Unit 2 by the lateral continuity of strong internal reflectors. In contrast to the parallel stratification of Unit 1, however, the reflectors within Unit 3 clearly show onlapping patterns that are the result of fill by turbidites, slumps, and other gravity-driven, leveling processes. In some instances, Reflector Purple is an angular unconformity that cuts most deeply into Unit 3 beneath the crest of the Ceara Rise. The Purple-to-basement interval may thicken slightly with increasing water depth (from roughly 150 to $200 \mathrm{~m}$ between the crest and the northeast foot of the rise), but this is difficult to gauge accurately because of the irregular basement and infilling character of the corresponding pre-Purple sediments.
Reflector Orange is a widespread and particularly strong reflector near the base of Unit 3 , and it is the deepest sedimentary feature traced in this preliminary study. Its especially high amplitude and unusually smooth character suggest an origin distinct from that of all other reflectors above it. In places, Reflector Orange overlies additional sedimentary units (usually within local basement lows); in other places, it appears to rest very close to basement; and in even other places, it appears to be absent on local basement peaks. Although Reflector Orange is observed on every dip line out to the $4500-\mathrm{m}$ isobath northeast of the Ceara Rise, two additional lines were run 50 $\mathrm{km}$ farther to locate the extent of this reflector. It appears from these lines that Reflector Orange feathers out onto typical oceanic crust along a line roughly parallel to and $150 \mathrm{~km}$ northeast of the rise crest.

Basement along the southwest flank of the Ceara Rise drops markedly beneath the Amazon Fan in a series of narrow (a few kilometers wide) fault blocks, and Reflector Orange is offset in equal measure with basement (Fig. 16). Reflector Purple, by contrast, usually drapes across these scarps, suggesting that the faulting was bracketed in age by Reflectors Orange and Purple.

DSDP Site 354 unfortunately was drilled on a local basement high (Fig. 11). The infilling strata of Unit 3 lap onto the flanks of this structural feature, and it is not possible to trace both Reflectors Purple and Orange to the drill site. Areas within $5 \mathrm{~km}$ of the drill site show that Reflector Purple is about $250 \mathrm{~ms}$ below Reflector Yellow, and that Reflector Orange is another $175 \mathrm{~ms}$ below Reflector Purple. This suggests that the stratigraphic level of Reflectors Purple and Orange at Site 354 ought to be at about 700 and 900 mbsf. The first may 
Figure 12. Cruise Ew9209 SCS Line 12 showing a series of northeast-dipping reflections within seismic Unit 2. Buried bedforms have consistent $5.5^{\circ}$ northeast dips.

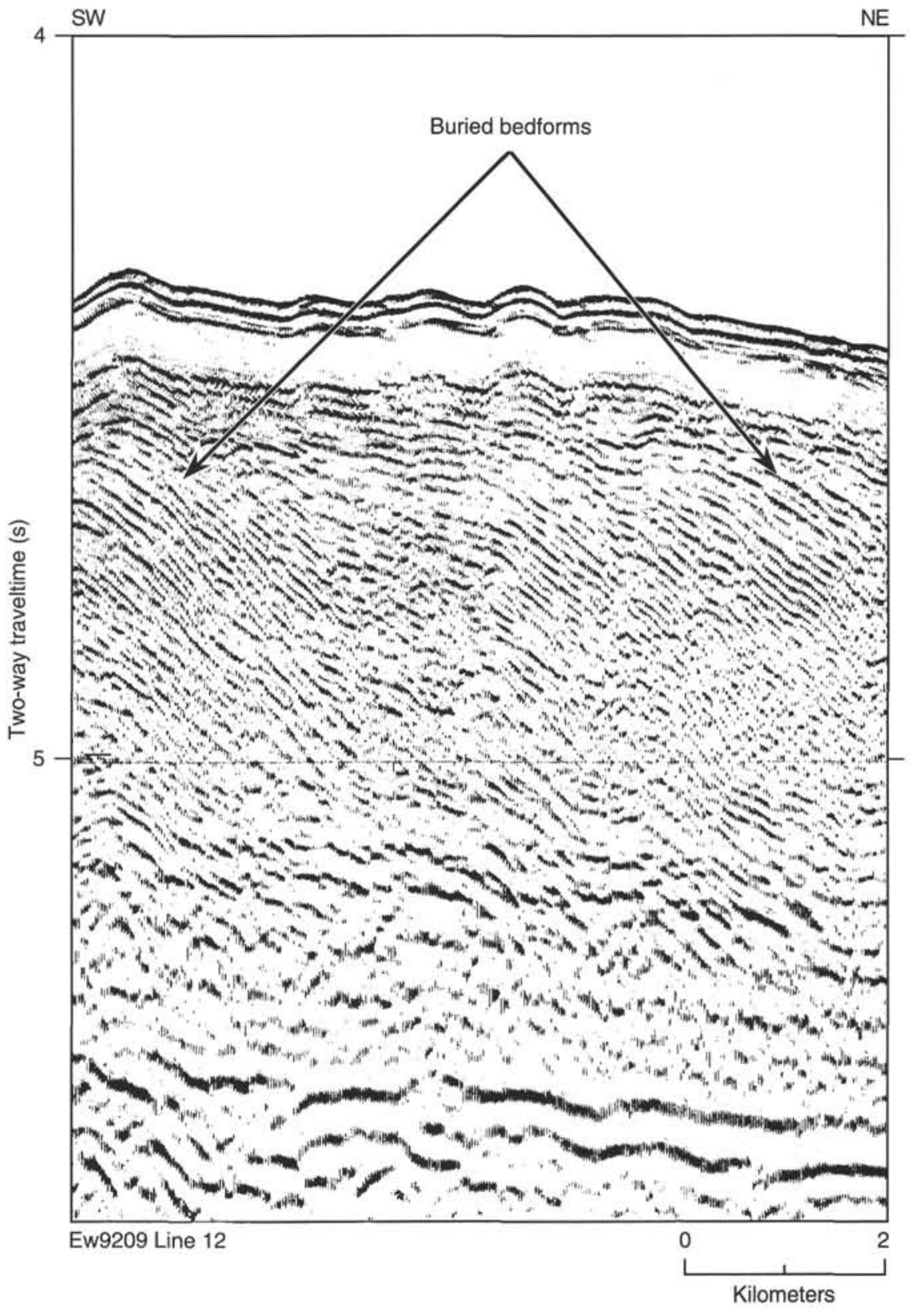

When traced southwest up the rise, however, this acoustic basement reflector changes abruptly to a smooth surface that we interpret as resulting from subaerial erosion. We base this conclusion on several observations: (1) the smooth character increases in most cases toward the rise crest (i.e., toward shallower paleodepths); (2) the interpretation that Reflector Orange is a flooded exposure surface makes entirely possible the case that underlying volcanic basement underwent subaerial erosion as well; (3) high-amplitude reflectors beneath Reflector Orange are locally preserved in small (several kilometer wide) basement troughs, and some examples appear to have been beveled at high angle; and (4) there are several regions where there is a hint of layering (Fig. 10) even within what at this point of our study is termed "basement" (i.e., the downward limit of acoustic stratification). Refraction velocities in these layered regions were measured between 3.9 and $4.7 \mathrm{~km} / \mathrm{s}$, values that are rather low for typical oceanic crust. Additional analyses could attempt to determine if this layering is evidence of "seaward-dipping reflectors" typically formed in the pre- and early-spreading evolution of large volcanic passive margins (Mutter et al., 1982). 


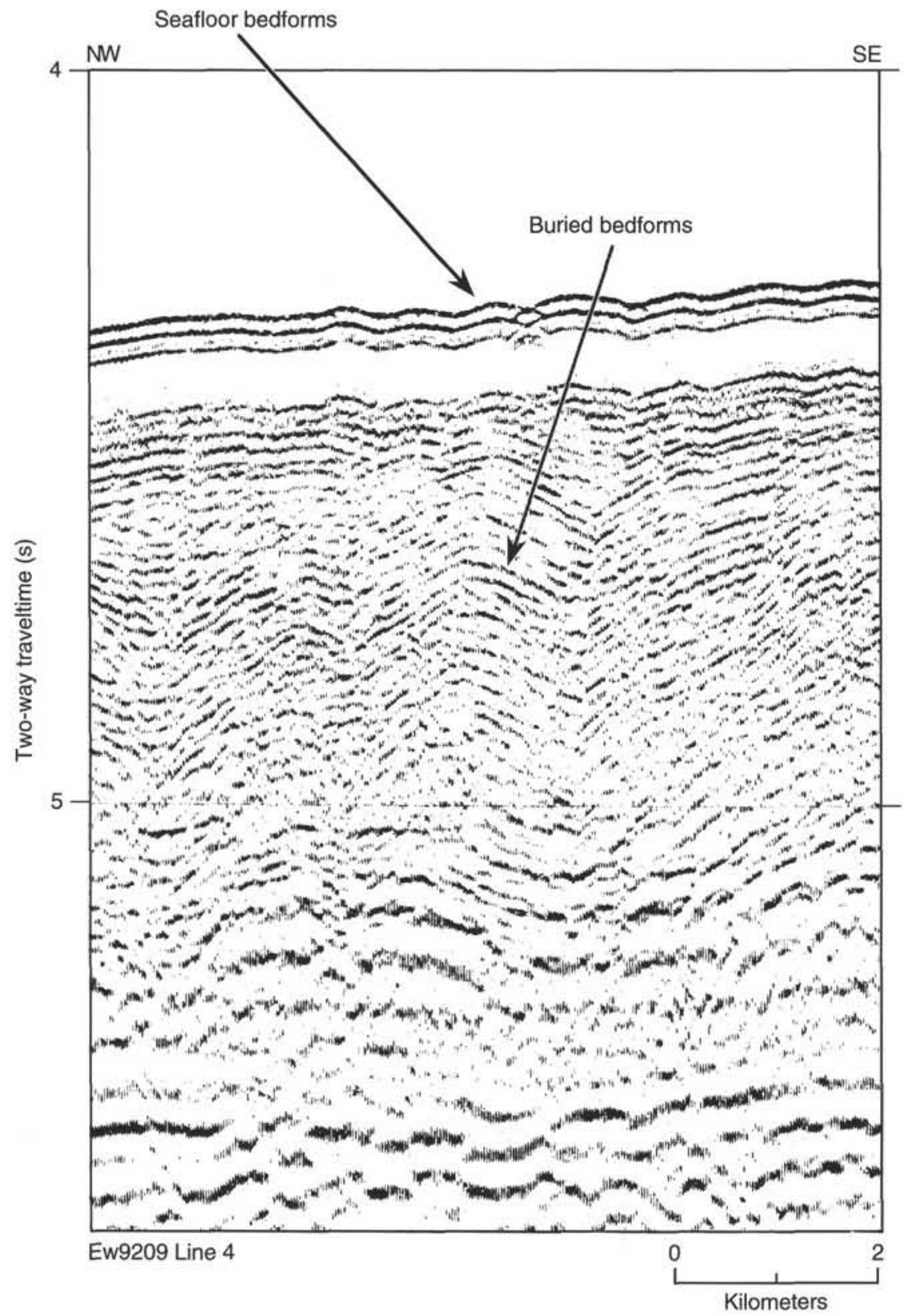

Figure 13. Cruise Ew9209 SCS Line 4 showing symmetric reflections within seismic Unit 2. Seafloor bedforms are $20 \mathrm{~m}$ high and $2 \mathrm{~km}$ long, whereas buried bedforms are $50 \mathrm{~m}$ high and $4 \mathrm{~km}$ long, with a symmetric $3.0^{\circ}$ dip.
Based on the mounded shape of some areas of "basement" that are onlapped by Reflector Orange, we suggest that reefs may be preserved above an underlying but poorly imaged volcanic layer, and that reflectors beneath Reflector Orange may be within a unit of platform carbonates. Known examples of reef material resting on a volcanic pedestal have demonstrated the difficulty in detecting the sedimentary/igneous contact with standard reflection profiles (e.g., ODP Leg 143).

\section{CONCLUSIONS}

Piston cores demonstrate moderately high $(2.5-5 \mathrm{~cm} / \mathrm{k} . \mathrm{y}$.$) and$ continuous sedimentation rates near the crest of the Ceara Rise back to the middle Pleistocene (pre-460 ka). Increasing carbonate dissolution in cores from the flanks of the rise result in lower sedimentation rates. The sediments are dominated by terrigenous input from the Amazon River; consequently, cores located closer to the Amazon Fan have higher sedimentation rates.
Echo-sounder and SCS profiles along the gentle northeast flank of the Ceara Rise suggest that gravity-induced sediment redistribution was significant only in the early history of the rise (seismic Unit 3; 80-50 Ma?). Bottom currents, by contrast, have long been an important agent in controlling the sediment history of the Ceara Rise. Hyperbolic echoes that indicate furrowed seafloor are seen in $3.5-\mathrm{kHz}$ profiles at $4480-4590 \mathrm{~m}$ water depth along the northeast foot of the Ceara Rise, proving that modern bottom-water flow is concentrated at this depth. Discontinuous, asymmetric reflectors in SCS profiles characterize the majority of the rise sediments (seismic Unit 2), and are interpreted to result from current-influenced bedform growth.

Evidence from spot-cored DSDP Site 354 tied to seismic profiles warns that large hiatuses are present on the Ceara Rise. However, these appear to be restricted to deeper water regions surrounding structural highs where slumping, carbonate dissolution, and topographically concentrated bottom currents were most active. Away from structural highs and shallower on the rise, more complete sequences should be encountered. 


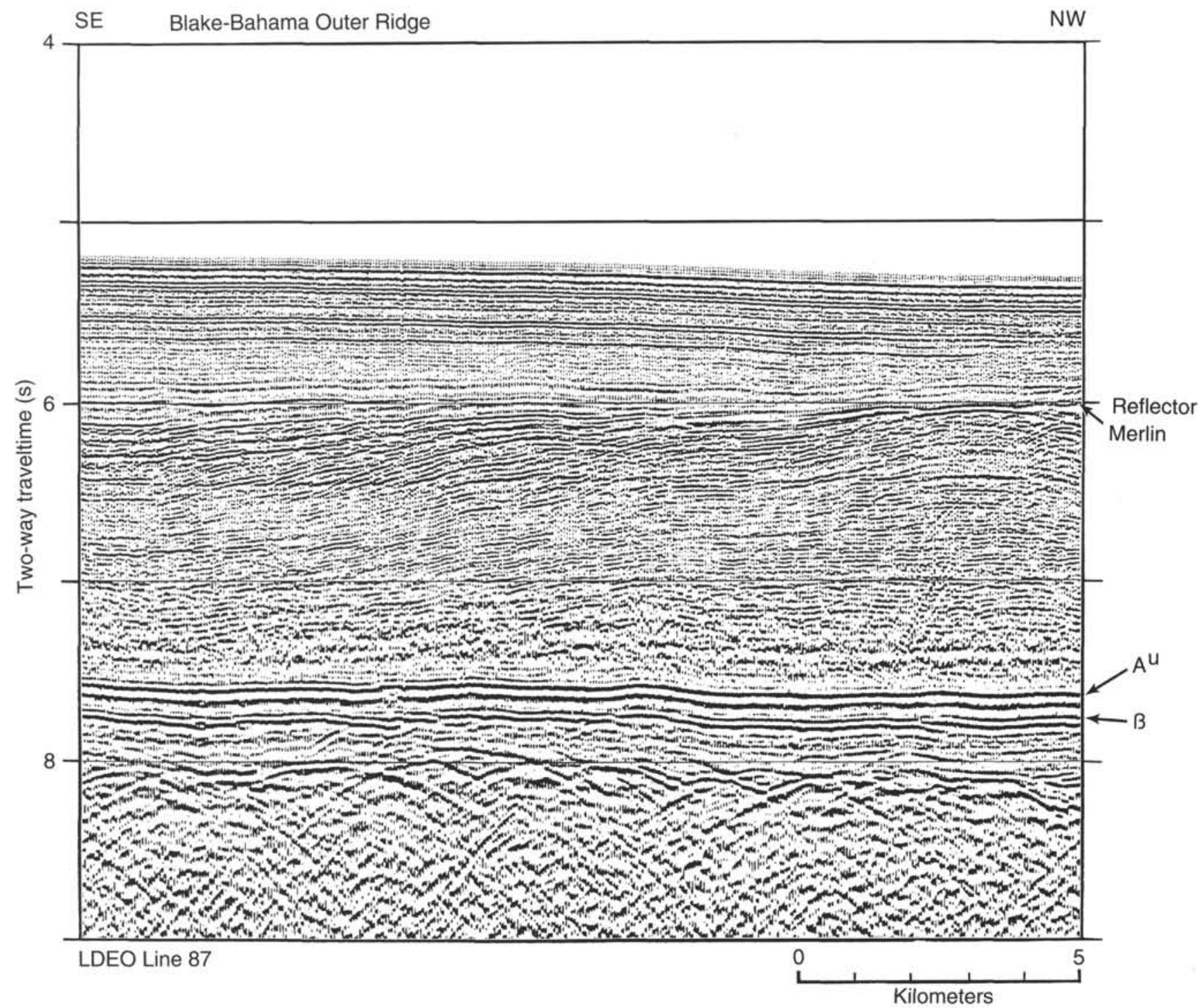

Figure 14. Multichannel seismic profile across the Blake-Bahama Outer Ridge (from LDEO Line 87). Reflector $\mathrm{A}^{\mathrm{u}}$ marks an erosional hiatus between Cretaceous and Miocene sediments; Reflector Merlin corresponds to upper middle Miocene sediments. Note the similarity in character between $\mathrm{A}^{\mathrm{u}}$-Merlin-seafloor in this profile and Reflectors Purple-Blue-seafloor in Figure 10.

Acoustic layering beneath the deepest reflectors of seismic Unit 3 suggests that a thick $(>1 \mathrm{~km})$ pile of subaerial flows may constitute the volcanic foundation of the Ceara Rise. Alternatively, this layering may be evidence of sediments within a basal carbonate platform. Either way, a strong, relatively smooth reflector near the base of the sedimentary section (Reflector Orange) is interpreted as an erosional surface marking the beginning of open-marine sedimentation.

\section{ACKNOWLEDGMENTS}

The professional assistance of the crew, officers, and scientific technical staff of the Maurice Ewing are gratefully acknowledged, as each helped to make this a comfortable and scientifically rewarding cruise. Shipboard processing of Hydrosweep data was made possible by S. O'Hara and the shore-based software developments by D. Chayes and D. Caress. J. Diebold wrote the JDseis seismic processing package; shipboard support in this effort was provided by J. Wright and L. Norby. J. Broda, G. Hovelsrud, D. Ostermann, J. Cullen, and J. Backman contributed greatly to the successful coring operations on board the Ewing. J. Backman contributed to the interpretations we present in this report. This is LDEO contribution 5259 and WHOI contribution 8811 .

\section{REFERENCES}

Berggren, W.A., Kent, D.V., and Flynn, J.J., 1985a. Jurassic to Paleogene: Part 2. Paleogene geochronology and chronostratigraphy. In Snelling, N.J. (Ed.), The Chronology of the Geological Record. Geol. Soc. London Mem., 10:141-195.

Berggren, W.A., Kent, D.V., and van Couvering, J.A., 1985b. The Neogene: Part 2. Neogene geochronology and chronostratigraphy. In Snelling, N.J. (Ed.), The Chronology of the Geological Record. Geol. Soc. London Mem., 10:211-260.

Curry, W.B., and Lohmann, G.P., 1990. Reconstructing past particle fluxes in the tropical Atlantic Ocean. Paleoceanography, 5:487-505.

\footnotetext{
Abbreviations for names of organizations and publications in ODP reference lists follow the style given in Chemical Abstracts Service Source Index (published by American Chemical Society).
} 
Damuth, J.E., 1975. Echo character of the western equatorial Atlantic floor and its relationship to the dispersal and distribution of terrigenous sediments. Mar. Geol., 18:17-45.

1977. Late Quaternary sedimentation in the western equatorial Atlantic. Geol. Soc. Am. Bull., 88:695-710.

Embley, R.W., Hoose, P.J., Lonsdale, P., Mayer, L., and Tucholke, B.E., 1980. Furrowed mud waves on the western Bermuda Rise. Geol. Soc. Am. Bull., Pt. 1.91:731-740.

Flood, R.D., and Hollister, C.D., 1974. Current-controlled topography on the continental margin off the eastern United States. In Burk, C.A., and Drake, C.L. (Eds.), The Geology of Continental Margins: New York (SpringerVerlag), 197-205.

Hays, D.E., Pimm, A.C., et al., 1972. Init. Repts. DSDP, 14: Washington (U.S. Govt. Printing Office).

Kumar, N., and Embley, R.W., 1977. Evolution and origin of Ceara Rise: an aseismic rise in the western equatorial Atlantic. Geol. Soc. Am. Bull., $88: 683-694$
Markl, R.G., Bryan, G.M., and Ewing, J.I., 1970. Structure of the BlakeBahama Outer Ridge. J. Geol. Res., 75:4539-4555.

Mountain, G.S., and Tucholke, B.E., 1985. Mesozoic and Cenozoic geology of the U.S. Atlantic continental slope and rise. In Poag, C.W. (Ed.), Geologic Evolution of the United States Atlantic Margin: New York (Van Nostrand Reinhold), 293-341.

Mutter, J.C., Talwani, M., and Stoffa, P.L., 1982. Origin of seaward-dipping reflectors in oceanic crust off the Norwegian margin by "subaerial seafloor spreading." Geology, 10:353-357.

Supko, P.R., Perch-Nielsen, et al., 1977. Init. Repts. DSDP, 39: Washington (U.S. Govt. Printing Office).

Thierstein, H.R., Geitzenauer, K.R., Molfino, B., and Shackleton, N.J., 1977. Global synchroneity of late Quaternary coccolith datum levels: validation by oxygen isotopes. Geology, 5:400-404.

\section{Ms 154IR-103}




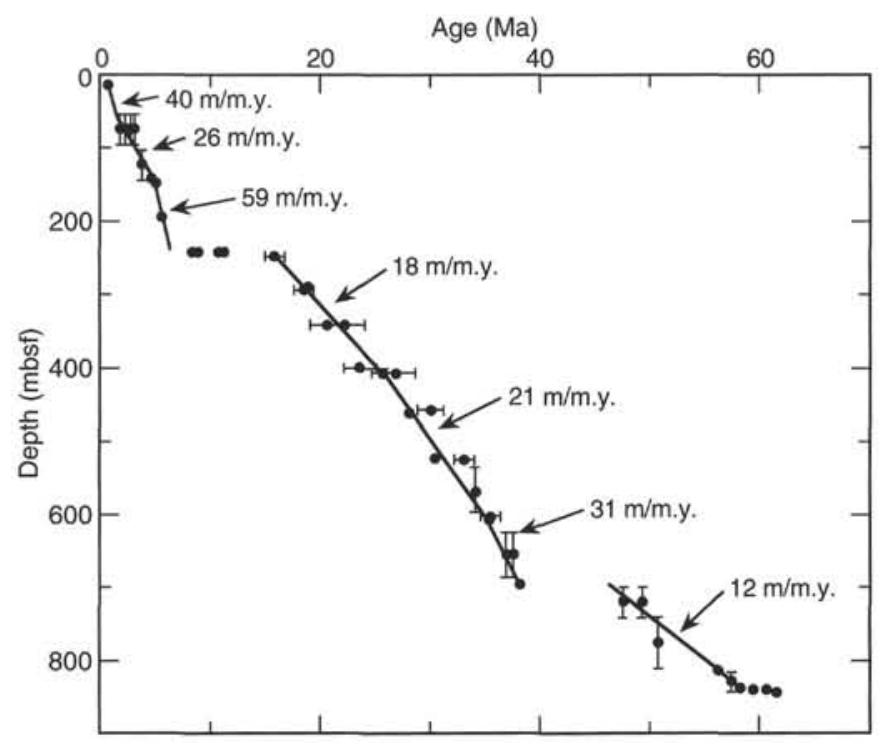

Figure 15. Sedimentation rate plot from DSDP Site 354, which has been recalculated using the Berggren et al. (1985a, 1985b) time scale. Biostratigraphy is from Supko, Perch-Nielsen, et al. (1977).

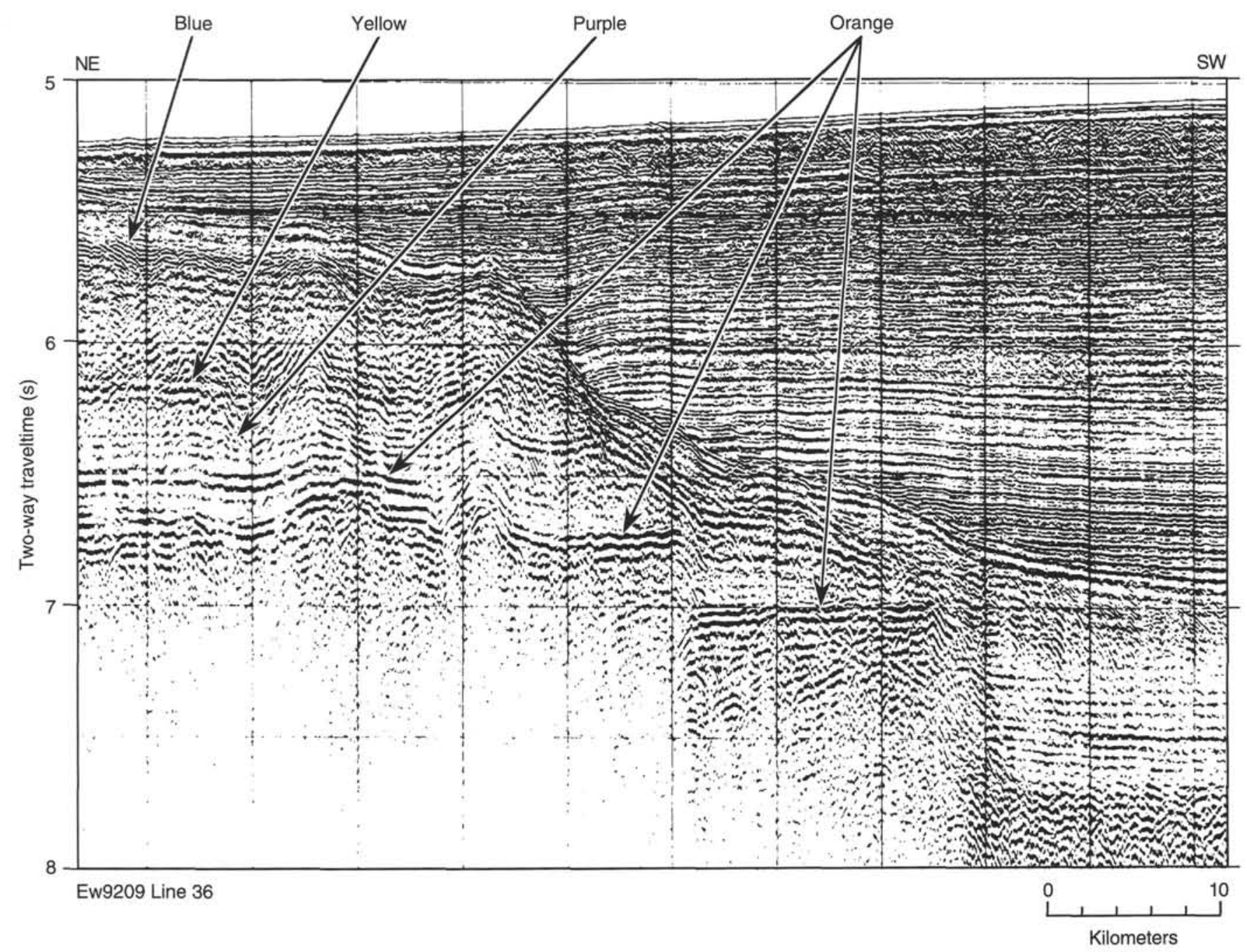

Figure 16. Cruise Ew9209 SCS profile at southwest base of the Ceara Rise and onto the Amazon Fan. Regional reflectors are shown. 